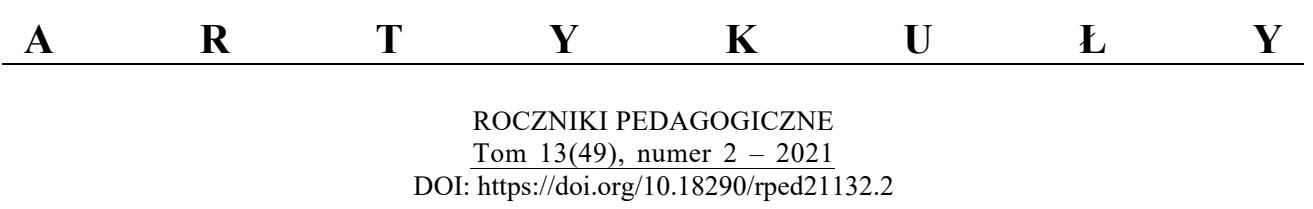

URSZULA OSTROWSKA

\title{
CZŁOWIECZEŃSTWO JAKO PROBLEM I WYZWANIE EDUKACYJNE
}

\section{UWAGI WSTĘPNE}

Przetaczające się przez współczesny świat intensywne i rozległe przemiany cywilizacyjne oraz społeczno-kulturowe z jednej strony są postrzegane jako ogromna szansa dla życia i rozwoju człowieka we wszystkich jego sferach, z drugiej natomiast strony owa dynamicznie ewoluująca rzeczywistość generuje wiele nowych problemów o narastającej złożoności, w tym zwłaszcza liczne zagrożenia, którym ludzkość nie zawsze potrafi należycie stawić czoła, jak również odpowiedzialnie zaświadczać w ich obliczu swoje człowieczeństwo. Skala tych problemów i zagrożeń wydaje się tak wielka, że sprawia wrażenie, iż niejednokrotnie przerastają one możliwości człowieka do zapanowania nad nimi i z wielu względów w sposób znaczący sytuuje się w epicentrum kwestii, które są postrzegane jako kluczowe. Pośród nich kwestia sposobów zaświadczania człowieczeństwa przez ludzi współczesnych przybiera rangę priorytetowego zadania współczesności i wyzwania wykraczającego w przyszłość. Tymczasem wiele pytań dotyczących istoty człowieczeństwa, nurtujących ludzkość od jej zarania i ewoluujących w toku dziejów aż do współczesności, pozostaje bez zadowalających odpowiedzi. Wprawdzie dość liczne grono reprezentantów różnych dyscyplin naukowych niejednokrotnie podejmuje w swoich rozważaniach problematykę człowieczeństwa, wytyczając rozmaite cele owym przedsięwzięciom oraz sytuując

Prof. dr hab. URSZUla OSTROWSKA - Katedra Teorii Wychowania i Metodologii, Wydział Humanistyczny, Akademia im. Jakuba z Paradyża w Gorzowie Wielkopolskim; adres do korespondencji: ul. Teatralna 25, 66-400 Gorzów Wielkopolski; e-mail: uostrowska@ajp.edu.pl; ORCID: https://orcid.org/0000-0003-2280-706X. 
je w różnorodnych kontekstach umożliwiających opisywanie eksplorowanych zagadnień na rozliczne sposoby i wzbogacając wiedzę z tego zakresu. W rezultacie ów stan rzeczy obrazuje stopień i rozmiary zaawansowania wiedzy na temat człowieczeństwa, jednakże wiele ważnych kwestii nadal pozostaje otwartych i ewidentnie skłania do dalszych eksploracji tejże problematyki.

Zawarta w tytule artykułu triada kategorii kluczowych: człowieczeństwo - problem - wyzwanie edukacyjne stanowi tropy wytyczające tok rozważań podjętych w niniejszym tekście. Rozpoczynam je od ujęć terminologicznych, a następnie prezentuję podjęte kwestie z jednej strony z perspektywy postrzegania człowieczeństwa jako priorytetowego problemu i wyzwania dla ludzkości, który wymaga intensywnych zabiegów epistemologiczno-eksploracyjnych, z drugiej strony jako konstytutywnej podstawy dla teorii i praktyki edukacyjnej ukierunkowanej na wnikliwe poznawanie człowieczeństwa, a także odpowiedzialne zaświadczanie przez podmioty edukacyjne tego fenomenu $\mathrm{w}$ universum antroposferycznym, w którym podejmowane próby doskonalenia elementów świata wartości nie mają kresu.

\title{
1. ISTOTA I WYMIARY CZŁOWIECZEŃSTWA
}

\begin{abstract}
Kultura jest właściwym sposobem „istnienia” i „bytowania” człowieka. [...] jest tym, przez co człowiek jako człowiek staje się bardziej człowiekiem: bardziej ,,jest”. [...] Wszystko, co człowiek „ma”, o tyle jest ważne dla kultury, o tyle jest kulturotwórcze, o ile człowiek poprzez to, co posiada, może równocześnie pełniej „być” jako człowiek, pełniej stawać się człowiekiem we wszystkich właściwych dla człowieczeństwa wymiarach swego bytowania ${ }^{1}$.
\end{abstract}

Jan Pawet II (1988, s. 55)

Rozległa i wieloaspektowa w swej złożoności problematyka człowieczeństwa wymaga interdyscyplinarnego podejścia i stanowi przedmiot zainteresowania wielu dyscyplin naukowych, takich zwłaszcza, jak filozofia, antropologia, socjologia, psychologia, pedagogika oraz teologia.

Pojęcie „człowieczeństwo” (humanitas), a także blisko niego sytuujące się pojęcie „ludzka godność” (dignitas hominis) kultura i nauka zawdzięczają Markowi Tulliuszowi Cyceronowi (łac. Marcus Tullius Cicero) (106-43 p.n.e.), pisarzowi, mówcy, filozofowi, politykowi, który spełniał się również w takich rolach, jak dowódca wojskowy, prawnik oraz kapłan rzymski (Stroh, 2013).

\footnotetext{
${ }^{1}$ Wszystkie wyróżnienia w cytatach pochodzą od autorki artykułu.
} 
Źródłosłowem dla terminu „człowieczeństwo” jest łacińskie słowo humanitas, humanitatis, oznaczające ludzkość, naturę ludzką, człowieczeństwo, ludzką postawę wobec kogoś, życzliwość, uprzejmość oraz szlachetne wychowanie i wykształcenie, a także kulturę osobistą (Winniczuk, 1985, s. 2), a przy tym w dociekaniach etymologicznych wskazuje się również przymiotnik humanus, znaczący ludzki, dotyczący ludzi, oraz res humanae, tłumaczone jako ludzkie losy, sprawy doczesne, ziemskie, godne człowieka (Kumaniecki, 1965, s. 236). Odpowiednikiem humanitas w słownictwie greckim są określenia: antropotes - człowieczeństwo lub anthropopatheia - ludzka wrażliwość, $k a$ lokagathia - piękno wynikające $\mathrm{z}$ dobra albo prepon - takt (Winniczuk, 1985) oraz paideia (gr. $\pi \alpha l \delta \varepsilon i \alpha$, łac. educatio). Owe dobro stanowi jedno z podstawowych pierwotnych pojęć etycznych utożsamianych z pojęciem bytu. W moralności dobro określa poprawność $\mathrm{w}$ sensie zgodności $\mathrm{z}$ normami moralnymi czynów oraz zachowań człowieka. Po raz pierwszy dobra moralne wyróżnił Sokrates (469-399 r. p.n.e.), który wyniósł je ponad wszystkie inne, takie jak dobra niższe i dobra pozorne. Wyrażał on przekonanie, że tylko to, co dobre, jest naprawdę pożyteczne, a przy tym wskazywał na cnotę będącą wiedzą jako prawdziwe dobro. Przekonywał zarazem, że człowiek zdobywający wiedzę osiąga dobro, a wraz z nim pożytek i szczęście. Etymologicznie słowo paideia, które jest wyrazem pochodnym od rzeczownika $\pi \alpha \hat{\imath} \varsigma$ (pais) (gr. pais znaczy dziecko) ${ }^{2}$, oznacza proces kształtowania człowieka od najmłodszych lat przez edukację i wychowanie, tudzież nadawanie kultury (Wasilewski, 2007). W czasach antycznych głównym celem paidei było ukształtowanie i wyedukowanie człowieka pięknego i mądrego na bazie wypracowanych przez starożytnych Greków najwyższych ideałów oraz najszlachetniejszych wzorów uznawanych za ogólnoludzkie.

Rdzeniem kategorii człowieczeństwo jest - rzecz jasna - człowiek, istota będąca człowiekiem w całej jego złożoności oraz różnorodności ludzkiego jestestwa w universum antroposferycznym, skupiającym jak w soczewce esencję cech i wartości przypisywanych gatunkowi ludzkiemu. Zatem z perspektywy uniwersalnej i ponadczasowej człowieczeństwo to zbiór wspólnych dla ludzi i kształtujących się na przestrzeni dziejów istotnych cech uznawanych za typowe i charakterystyczne dla gatunku ludzkiego, w tym takich zwłaszcza, jak racjonalność - wyrażająca się najwyższym rozwojem psychiki i życia

\footnotetext{
${ }^{2} \mathrm{~W}$ językach europejskich termin ,paideia” nie ma prostego tłumaczenia. Nie oznacza bowiem to słowo procesu wychowania w takim sensie, jak bywa on rozumiany współcześnie w kontekście doświadczeń związanych z jego realizacją. Szerzej podejmowałam tę problematykę w innym miejscu (zob. Ostrowska, 2021a).
} 
społecznego, sposoby formułowania myśli oraz bogactwo posługiwania się językiem, a także wyrażania uczuć, jak również różnorodność rodzajów ludzkich zachowań, w tym przede wszystkim posiadanie kultury i zdolność do jej tworzenia, tudzież do przeżywania idei i norm moralnych, jak i wartości związanych z sacrum (wartości religijne) (Mariański, 2017, s. 9). Owe konstytutywne cechy charakterystyczne dla ludzi wyróżniają człowieka spośród wszystkich innych istot żywych, który jako synergiczne compositum ciała i ducha, woli i intelektu, nie tyle jest (non esse), co w aktywności swego jestestwa ustawicznie staje się (posse), spełniając się wielorako, do czegoś aspiruje, dąży, jak również coś dezawuuje, kontestuje, potępia bądź zdecydowanie odrzuca. Ponadto z perspektywy zaświadczania człowieczeństwa niezwykle ważnym kierunkiem rozważań jest to, że w dynamice nieprzeniknionego bogactwa swego istnienia człowiek w sposób świadomy spełnia się nie tylko jako „byt w sobie” oraz jako „byt dla siebie”, lecz egzystuje także jako „byt dla innych”.

Obejmując swym zakresem ogół uznawanych za charakterystyczne dla gatunku ludzkiego cech, wartości i antywartości, kategoria człowieczeństwo przybiera bardzo szeroki wymiar i z tej racji niejednokrotnie pojawiają się rozliczne wątpliwości oraz kontrowersje dotyczące opisów rozumienia tego pojęcia, doprowadzające do wyłonienia się dwóch głównych orientacji. Jedna z nich przypisuje miano człowieczeństwa ludziom ze wszech miar świadomie i odpowiedzialnie zaświadczającym swoje człowieczeństwo. Przyjmuje się $\mathrm{w}$ tejże orientacji założenie, że osoba ludzka jest z natury dobra i w swej istocie przede wszystkim dąży do dobra, toteż słowo „człowiek” należy wypowiadać z dumą, w tym skłaniać się ku uznaniu, iż „[...] w ludziach więcej rzeczy zasługuje na podziw niż na pogardę" (Camus, 1987, s. 199). Na przykład aksjonormatywne pojmowanie człowieczeństwa prezentuje filozof, logik i etyk, Tadeusz Czeżowski (1889-1981), wskazujący na trzy współistniejące postawy człowieka wobec świata, które wyznaczają rozumienie tego fenomenu, tj. postawa poznawcza, praktyczna (wartościująca) oraz refleksyjna. Filozof uzasadnia swoje stanowisko w tej mierze następująco: „Owa całość bytu [...] staje się nam tym bliższa, im dokładniejsze jest nasze poznanie jej przejawów w świecie dostępnym naszej wiedzy, lecz jeszcze bardziej zbliżamy się do niej, ujmując jej doskonałość w ocenach wartości i jej piękno w kontemplacji estetycznej” (Czeżowski, 1989, s. 45-46).

Również pedagog i filozof, teoretyk aksjologii pedagogicznej oraz antropologii filozoficznej, Władysław Cichoń (1924-1985), eksponując rolę wychowania w usprawnianiu wychowanków do urzeczywistniania własnego człowieczeństwa, zastrzegał, że 
Być człowiekiem to przede wszystkim działać w imię najwyższych wartości uznanych za swoiście ludzkie. Wynika stąd doniosłe i wyjątkowo odpowiedzialne zadanie dla teorii wychowania. Wychowanie ma bowiem pomóc wychowankowi w stawaniu się na miarę swoich najlepszych możliwości, ma usprawnić go do urzeczywistniania własnego czlowieczeństwa i osiągnięcia celów, jakie stawia przed nim doskonalenie wyboru pozytywnych wartości społecznych i moralnych (Cichoń, 1996, s. 164).

Natomiast druga orientacja przyjmowana w postrzeganiu człowieczeństwa odnosi się do ogółu ludzkich cech i zachowań, zarówno tych najbardziej wzniosłych, szlachetnych, szczytnych, ze wszech miar pożądanych, jak i owych nagannych, nikczemnych, niegodnych miana człowieka, ale będących jego udziałem, w tym nawet takich, które są uznawane za najbardziej uwłaczające człowiekowi. W tejże orientacji człowiekowi, który nie jest bytem idealnym, wprawdzie przyzwala się na bycie omylnym, czyli dopuszczalne jest popełnianie przez niego błędów czy nieprawidłowości. Niemniej jednak przyjmuje się zarazem stanowisko, że taki stan rzeczy w żadnym razie nie zwalnia człowieka z powinności poddawania owych zdarzeń refleksji oraz czerpania $\mathrm{z}$ nich nauki $\mathrm{w}$ celu unikania $\mathrm{w}$ przyszłości tego typu nieprawidłowości. Ta zasada znalazła swój wyraz już w czasach antycznych, m.in. dzięki Lucjuszowi Anneuszowi Senece (Starszemu) (Lucius Annaeus Seneca, ok. 55 p.n.e.-40 n.e.), który orzekał następująco: Humanum est errare [„Mylić się jest rzeczą ludzką"], z czasem dopisywano do tej sentencji frazy zastrzegające, iż nieczynienie starań o wyzbycie się błędów i powielanie ich zaświadcza o ludzkiej głupocie ${ }^{3}$.

W interdyscyplinarnej literaturze przedmiotu zwraca się uwagę, iż człowieczeństwo skupia $\mathrm{w}$ sobie niczym w soczewce wszystkie możliwe indywidualne oraz różnych zbiorowości społecznych wartości, a także antywartości, które są przypisywane gatunkowi ludzkiemu, nadając w tenże sposób rozważanej kategorii szeroki zakres znaczeniowy. Eksponuje się zarazem, że ów fenomen manifestuje się przede wszystkim w działalności świadomej,

\footnotetext{
${ }^{3}$ Seneka Starszy, Controversiare, IV 3. Sentencja owa jest nową wersją myśli Teognisa, którą w języku łacińskim wypowiadał już Cyceron. Zacytowana została przez św. Hieronima ze Strydonu w następującym szyku: „Errare humanum est” (Listy 57, 12) i w takiej postaci rozpowszechniona (zob. Markiewicz, Romanowski, 1990, s. 589). Owa myśl Cycerona brzmi: „Cuiusvis hominis est errare, nullius nisi insipientis in errore perseverare” [„Każdego człowieka mylić się własnością jest, lecz tylko głupiego trwać w błędzie” / „Każdy człowiek może zbłądzić, uparcie trwać przy błędzie tylko głupi (może)"], a także u innych autorów greckich i rzymskich. Sentencja owa zawarta jest także w Piśmie św., w postaci: „Errare humanum est, in errore perseverare diabolicum” [„Błądzenie jest rzeczą ludzką, ale trwać w błędzie diabelską”] (zob. Czapiński, 1892, s. 149-150).
} 
ukierunkowanej na życie z innymi, we wspólnocie, jako przywilej jednostki zachowującej się rozumnie, wrażliwej moralnie, uspołecznionej, twórczej $\mathrm{i}$ - w przypadku popełnianych błędów - podejmującej starania w zakresie ich naprawienia (Gajda, 2003, s. 149-150). Zarazem niejednokrotnie zastrzega się, że dotychczasowy stan wiedzy z tego zakresu nie uprawnia do jednoznacznych rozstrzygnięć.

Rozważając zagadnienie przynależności elementarnego szacunku dla każdego człowieka, stanowiącego gwarant niemożności unicestwienia tkwiącego w nim człowieczeństwa nawet wtedy, gdy dany człowiek żyje w sposób moralnie naganny, na uzasadnienie owego stanowiska socjolog specjalizujący się w socjologii moralności i socjologii religii, ks. Janusz Mariański (ur. 1940) (2017, s. 17), odwołując się m.in. do poglądów innego socjologa, Janusza Sztumskiego (ur. 1930), na ten temat (Sztumski, 1994, s. 155), w uwagach końcowych konkluduje następująco:

Socjologia zajmuje się co prawda moralnością przede wszystkim jako pewną
postacią życia społecznego, dostępną badaniom empirycznym, nie daje zaś
odpowiedzi na pytanie o istotę człowieka i sens jego działań, ale może i po-
winna go postrzegać w sposób integralny, a więc w pełni człowieczeństwa
i w osobowych relacjach międzyludzkich (Mariański, 2017, s. 18).

Trzeba przyznać, że jakkolwiek od nauk o człowieku nie sposób uzyskać wprost odpowiedzi na konstytutywne pytania dotyczące istoty ludzkiej i człowieczeństwa, to niemniej jednak w toku zmagania się z wieloma problemami z tego zakresu można podążać za socjologiem Janem Szczepańskim (1913-2004), orzekającym, iż

Człowieczeństwo jest ideą, jest wysublimowanym wytworem intelektu, jest czymś podobnym jak dobro, sprawiedliwość, prawda. [...] Idea czlowieczeństwa jest potrzebna jako miara, jako wzór, jako drogowskaz. Jest ona zbiorem cech idealnych, jest konstruktem złożonym $\mathrm{z}$ cech wyidealizowanych, pożądanych, z marzeń filozofów i teologów konstruujących człowieka $\mathrm{z}$ wyobrażonych elementów odbicia doskonałości stwórcy (Szczepański, 1980, s. 73).

Niemniej jednak w piśmiennictwie przedmiotu niejednokrotnie zastrzega się, że człowiek, popełniając czyn niegodziwy, wprawdzie nie przestaje być osobą i nie traci swej osobowej godności, jednakże wystawia na szwank siebie samego i swoje człowieczeństwo, pomniejszając jego rangę, jako że

[...] uderza sam w siebie - i to rani siebie głębiej, niż należnych im dóbr, może im przysparzać bólu - ale nie może ich uczynić moralnie złym. Natomiast może 
niejako „pomniejszyć” swoje czlowieczeństwo działaniem nieodpowiadającym jemu samemu jako osobie (Szostek, 1998, s. 109).

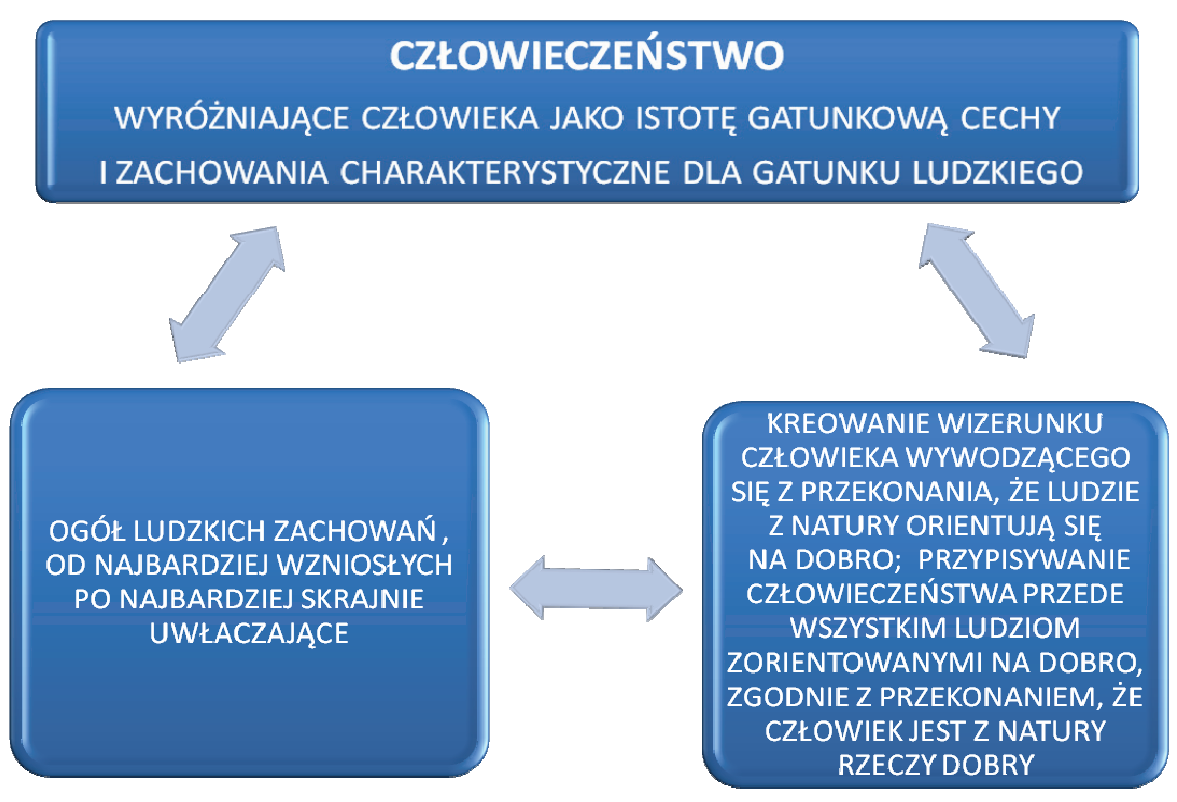

Rysunek 1. Rozumienie/pojmowanie człowieczeństwa.

Źródło: koncepcja własna ${ }^{4}$.

Zarówno szerokie, jak i węższe ujęcie człowieczeństwa zostało zobrazowane na Rysunku 1, na którym jeden z elementów odniesiono do ogółu ludzkich cech i zachowań, od najbardziej wzniosłych do skrajnie uwłaczających istocie ludzkiej (szerokie znaczenie). Natomiast drugi element wskazuje na przypisywanie miana człowieczeństwa będącego wartością i skupiającego w sobie najistotniejsze pozytywne cechy przede wszystkim ludziom zorientowanym na dobro własne, innych i świata, zgodnie z przekonaniem, że człowiek jest z natury rzeczy dobry i zaświadcza to w swoim życiu na rozmaite sposoby (węższe znaczenie).

Wywodzące się z czasów antycznych znaczenie pojęcia humanitas przywodzi na pamięć wypowiedź na temat człowieka starożytnego poety greckiego, głównego przedstawiciela komedii nowej i komedii charakterów - Menandera (342-291 p.n.e.), a mianowicie: „Jaką wdzięczną rzeczą jest człowiek,

\footnotetext{
${ }^{4}$ Rozważając zagadnienie człowieczeństwa w monografii na ten temat, wykorzystałam (z nieco innym opisem) rycinę graficznie prezentującą podejmowane kwestie (por. Ostrowska, 2020, s. 124 n.).
} 
jeśli jest człowiekiem"5, oraz słowa komediopisarza rzymskiego, Terencjusza (Publius Terentius Afer, ok. 195-ok.159 p.n.e.), stwierdzającego następująco: Homo sum; humani nihil a me alienum puto [„Człowiekiem jestem; nic, co ludzkie, nie jest mi obce"]. Na przestrzeni dziejów wielość i różnorodność rozumienia istoty człowieczeństwa w literaturze przedmiotu odzwierciedlają rozlicznie podejmowane próby ujmowania istoty człowieka w postaci formułowania syntetycznych swoistych określeń, które eksponują dominantę przypisywanych mu cech, o czym zaświadcza funkcjonujące bogactwo takich kategorii, w których konstrukcji posłużono się terminologią łacińską ${ }^{6}$, na przykład: animal rationale - stworzenie rozumne; animal metaphysicum - stworzenie zdolne do doznań pozazmysłowych; homo religiosus - człowiek religijny; homo faber - człowiek zręczny; homo ludens - człowiek bawiący się; animal symbolicum - stworzenie posługujące się symbolami; zoon politikon - z gr. istota społeczna; homo scientificus - człowiek zdobywający wiedzę i wykształcenie; homo eruditus - osoba ceniąca rozległą wiedzę, wykształcenie; homo moralis - człowiek moralny, ponoszący za swoje postępowanie odpowiedzialność; homo aestheticus - osoba ceniąca piękno; homo philosophicus - poszukujący sensu swego życia, miłośnik mądrości; homo socialism - osoba o orientacji społecznej, poszukująca więzi z innymi; homo domesticus - człowiek zamieszkujący w domu, w kraju rodzinnym, w ojczystej krainie; homo oeconomicus - osoba ukierunkowana na realizację potrzeb materialnych; homo ludens - człowiek preferujący w życiu odpoczywanie i zabawę; homo fatalis - człowiek nieszczęsny, zagubiony przeznaczeniem losu; homo insciens - człowiek, który nie wie, w tym oto sensie, że istota ludzka nigdy z dozą pewności nie wie, co to znaczy tak naprawdę być człowiekiem. I jeszcze wiele, wiele innych, zdawałoby się nie do wyczerpania, określeń przypisywanych człowiekowi oraz obrazujących wyróżniane elementy jego człowieczeństwa. $Z$ jednej strony retoryka tego typu esencjalnych w swym kształcie konstruktów na temat człowieka zaświadcza o wprost niewyczerpalnej pomysłowości ludzi w zakresie poszukiwania oryginalnych, najtrafniejszych sposobów językowego odzwierciedlania rzeczywistości człowieczej, z drugiej strony natomiast nade wszystko uwidacznia się tu kwestia

\footnotetext{
${ }^{5}$ Jeden z czołowych filologów klasycznych XX, Werner Jaeger, w przedmowie do wydania angielskiego drugiego tomu swojego obszernego dzieła, cytuje następująco poetę Menandera: „To, czego nikt nie może zabrać człowiekowi - to paideia” (Jaeger, 1964, s. 22).

${ }^{6}$ Wbrew dość powszechnemu mniemaniu łacina nie jest językiem „stricte” martwym w pełnym tego słowa znaczeniu, czego dowodzi jej ciągły rozwój oraz powszechne jej stosowanie, zwłaszcza w naukach przyrodniczych (nowo odkrywanym gatunkom organizmów nadawane są nazwy łacińskie), w medycynie, w astronomii (nazwy gwiazdozbiorów), w chemii (nazwa pierwiastków) i rzecz jasna w teologii.
} 
wymykania się istoty ludzkiej z zabiegów poddawania jej definicyjnym ujęciom, bez względu na wytyczone cele oraz przyjmowane kryteria owych przedsięwzięć.

Kontynuując powyższy wątek $\mathrm{w}$ dociekaniach istoty i wymiarów człowieczeństwa, w tym miejscu odrębnie odniosę się do jeszcze jednego tego typu konstruktu, a mianowicie do retoryki homo ethicus, którego pomysłodawcą jest filozof, Henryk Elzenberg (1887-1967). Zajmujący się głównie etyką, estetyką, aksjologią oraz historią filozofii, w swoim dzienniku filozoficznym, który prowadził przez prawie 56 lat (w latach 1907-1964), m.in. stwierdził, że istnieją ludzie obdarzeni tak zwaną wolą etyczną. Pragną oni urzeczywistnienia dobra oraz unikania zła. Dla części owych ludzi obdarzonych wolą etyczną spełnienie jej jest bardzo ważnym, a nawet naczelnym celem życia. Właśnie takim ludziom Elzenberg przypisał miano homo ethicus, czyli człowieka moralnego, dla którego „,...] własna moralność leży szczególnie jakoś na sercu i który do niej świadomie dąży, oczywiście właśnie dlatego, że się całkiem w porządku nie czuje (Elzenberg, 1966, s. 215). W toku dalszych rozważań na ten temat autor doprecyzował zaproponowany konstrukt następująco:

\footnotetext{
Homo ethicus [...] to nie ten rodzaj człowieka, który by po prostu dobrze chciał czynić, któremu by wystarczyło powiedzenie prawdy, wytrwanie w walce, sprawiedliwy wyrok, akt wyrzeczenia [...]. On nie czynić chce dobrze, ale być dobrym, zaś być dobrym to może znaczyć sporo rzeczy bardzo wewnętrznych (s. 226).
}

Nic więc dziwnego, że filozof Maria Gołaszewska (1926-2015), dla której mistrzem naukowym był Roman Ingarden, rozważając pod koniec ubiegłego stulecia istotę $\mathrm{i}$ istnienie wartości, ustanowiła człowieczeństwo uniwersalną wartością najwyższą w antroposferze. Zaznaczyła przy tym, iż z perspektywy należących do rzędu możliwości, człowieczeństwo stanowi w universum antroposferycznym punkt odniesienia dla wszelkich innych wartości oraz uzasadniła powinność ich zaistnienia (Gołaszewska, 1990, s. 38 n.). Człowiek bowiem jako podmiot obecny $\mathrm{w}$ rzeczywistym świecie jawi się jako potencjalność, która może się aktualizować. W aspekcie przedmiotowym autorka utożsamiła wartość człowieczeństwa $\mathrm{z}$ bytem mającym status transcendentalnej własności bytu (Gołaszewska, 1990, s. 37).

Natomiast filozof Roman Ingarden (1893-1970), uczeń twórcy fenomenologii, Edmunda Husserla, w swoich rozważaniach aksjologicznych tak oto eksponował nieodzowność transgresyjnego wymiaru człowieczeństwa istoty 
ludzkiej będącej twórcą wartości: „Natura ludzka polega na nieustannym wysiłku przekraczania granic zwierzęcości tkwiącej w człowieku i wyrastania ponad nią człowieczeństwem [...]" (Ingarden, 1973, s. 26).

Fenomen człowieczeństwa nie jest rzecz jasna stanem constans. Sygnalizując kwestię istoty i granic człowieczeństwa, francuski pisarz i ilustrator, Vercors (właśc. Jean Marcel Bruller; 1902-1991), zwrócił uwagę na wymiar procesualny tego fenomenu następująco: „Człowieczeństwo nie jest stanem, w którym przychodzimy na świat. To godność, którą trzeba zdobyć” (1956).

Kontynuator tradycji fenomenologii Romana Ingardena - filozof Władysław Stróżewski (ur. 1933), zajmujący się aksjologiczną strukturą człowieczeństwa - zwrócił uwagę ponadto na postrzeganie tego fenomenu przez pryzmat idei regulatywnej mającej znaczenie porządkujące proces poznania i pisze na ten temat, że: „Człowieczeństwo jest nie tylko stanem zastanym, lecz zadaniem. Jest ideą, zarówno w platońskim, jak i kantowskim rozumieniu tego słowa: ideą regulatywną. I pozostanie dla nas wyzwaniem [...]" (Stróżewski, 2002, s. 36).

Zasygnalizowanej $\mathrm{w}$ zacytowanym fragmencie kwestii wyzwania przeznaczam ostatnią część artykułu. Tymczasem pierwszą część niniejszego tekstu, zatytułowaną „Istota i wymiar człowieczeństwa”, kończę ponownym odwołaniem się do kwestii, od których rozpoczynałam rozważania stanowiące główny przedmiot uwagi artykułu, ujmując w tenże sposób podjętą problematykę w swoistą klamrę, która $\mathrm{z}$ jednej strony zamyka tę sekwencję, z drugiej strony natomiast orientuje na dalszy tok rozważań jako „otwarty problem". A mianowicie nawiązuję tu do wyrażonego przez Stróżewskiego poglądu, że u podstaw każdego projektu paidei ,[...] leży przekonanie o niedoskonałości człowieka", i uzasadniającego, że

[...] Człowiek, który się staje, musi zawierać w sobie nie tylko możność - dynamis - warunkującą sam proces stawania się, ale musi mieć wytyczony cel-ideał czy ideę, wedle której i ku której owo stawanie się ma być kierowane. Nazwijmy wreszcie tę ideę po imieniu; nie jest to przecież nic innego jak idea czlowieczeństwa (Stróżewski, 1992, s. 37). 


\title{
2. PERSPEKTYWA PROBLEMU
}

\author{
Położysz największe zasługi dla państwa nie przez \\ wznoszenie wysokich gmachów, ale przez kształtowanie \\ wielkich dusz. Lepszą jest bowiem rzeczą, aby w małych \\ chatach pomieszkiwały wielkie dusze, niż żeby w wielkich \\ gmachach czaiły się nikczemne dusze niewolników. \\ Epiktet (1961, s. 501)
}

Przypisywanie kategorii człowieczeństwa znamienia problemu ewidentnie kieruje uwagę na kwestię ważną, wymagającą poważnego potraktowania i zarazem z wielu względów trudną, sprawiającą kłopot, toteż wzbudzającą niepokój i skłaniającą do wnikliwych przemyśleń oraz do rozstrzygania owego stanu rzeczy ze szczególną uwagą, wymagającą skoncentrowania, ale także determinacji. W potocznym poznaniu problemy na ogół wyrastają z potrzeb życia codziennego i na ogół bywają postrzegane spontanicznie bądź są rozważane doraźnie i raczej w sposób niezorganizowany. Przeważa bowiem w owym podejściu do sytuacji, którą na co dzień określa się jako problemowa, tzw. poznanie zdroworozsądkowe, cechujące się zazwyczaj ogólnikowością, brakiem dokładności, a także niespójnością oraz subiektywnością i na dodatek ów proces bywa bardziej lub mniej zdominowany emocjonalnie oraz wolicjonalnie.

Natomiast problemy formułowane w postępowaniu naukowym mają charakter stricte racjonalny, dyskursywny, systematyczny i metodyczny oraz metodologiczny. Wywodzący się z języka greckiego termin „problem” (gr. problèma, problếmatos; łac. problema, -atis) oznacza przeszkodę lub trudność, które są rozwiązywane zgodnie $\mathrm{z}$ obowiązującymi w nauce procedurami. Każdy problem naukowy stanowi swoistą trudność poznawczą w sensie artykułowania jakiegoś braku dostrzeganego w stanie danej wiedzy naukowej, toteż wymaga pokonywania rozmaitych przeszkód napotykanych na drodze epistemologiczno-eksploracyjnej prowadzącej do jego rozstrzygnięcia.

Formułowanie problemu naukowego z jednej strony wskazuje na rangę przypisywaną temu fenomenowi, którego wnikliwe eksplorowanie wymaga podejścia umożliwiającego pozyskiwanie uznawanej za najlepszą pod względem poznawczym wiedzy naukowej, najbardziej adekwatnie opisującej rzeczywistość, a także spełniającej wymagane procedury, w tym m.in. takie jak intersubiektywna komunikowalność oraz intersubiektywna kontrolowalność/ 
weryfikowalność 7 . Z drugiej strony formułowanie problemów naukowych umożliwia orientowanie się w stanie - wyłaniającej się na fundamentach zasobów dotychczasowej wiedzy na temat będącej przedmiotem uwagi niniejszego opracowania kwestii człowieczeństwa - niewiedzy, której granice nie sposób dokładnie zakreślić.

Oczekiwania dotyczące wzbogacania zasobów wiedzy na temat człowieczeństwa kierują szczególną uwagę ku predestynowanym do ich spełniania naukom humanistycznym i naukom społecznym, a także naukom przyrodniczym reprezentującym dość bogate spektrum dyscyplin naukowych zajmujących się człowiekiem i jego światem. Tym niemniej w dotychczasowych osiągnięciach nauki właśnie wiedza o człowieku okazuje się z wielu względów niewystarczająca, wręcz jawi się jako nazbyt skromna i w swym ubóstwie oraz rozmaitych ograniczeniach niespełniająca oczekiwań ludzi współczesnych, toteż - pomimo odnotowywanego w jej zasobach znacznego postępu - niezmiennie wzbudza ona spośród wszystkich rodzajów wiedzy największy niedosyt ${ }^{8}$.

Niewątpliwie sytuację rozwoju wiedzy na temat człowieczeństwa znacznie komplikuje jej interdyscyplinarne rozproszenie oraz ciągle odczuwana jako nazbyt uboga literatura przedmiotu na ten temat. Owe trudności potęguje nadto jeszcze ustawiczne ewoluowanie fenomenu człowieczeństwa jako problemu sytuowanego w wielorako zróżnicowanej, dynamicznie zmieniającej się rzeczywistości. Stanowiąc złożoną strukturę problemową, człowieczeństwo bez wątpienia wymaga przeto pieczołowicie zaprojektowanych procedur epistemologiczno-eksploracyjnych oraz zmagania się z prymatem pytań nad możliwościami uzyskania satysfakcjonujących odpowiedzi na nie. Natomiast przypisywanie kwestii człowieczeństwa znamienia problemu otwartego nie oznacza wszakże jego wadliwości czy ułomności, lecz zgoła przeciwnie, nade wszystko wskazuje na złożoność i rozległość tejże ustawicznie ewoluującej problematyki, dla której nie sposób ściśle wytyczyć zakres możliwych rozwiązań ${ }^{9}$. A przy tym jeszcze uwyraźnia ów stan rzeczy nietelosujący potencjał przedmiotu badań, ujawniający się zwłaszcza na styku wiedzy z niewiedzą, gdzie na owej - jeśli można to tak określić - „macierzy problemowej" wyłania się nowe spektrum problemów ad deliberandum.

\footnotetext{
${ }^{7}$ Szerzej i z innej perspektywy problemowej piszę na ten temat w tekście zgłoszonym do druku (Ostrowska, 2021b).

${ }^{8}$ Zwracałam uwagę na tę kwestię w innym ujęciu problemowym (Ostrowska, 2021b).

${ }^{9}$ Problemy otwarte niekiedy w sposób nieuprawniony są postrzegane jako źle określone i niesłusznie zarzuca się im ogólnikowość, czyli zbyt niski poziom zawartych informacji.
} 


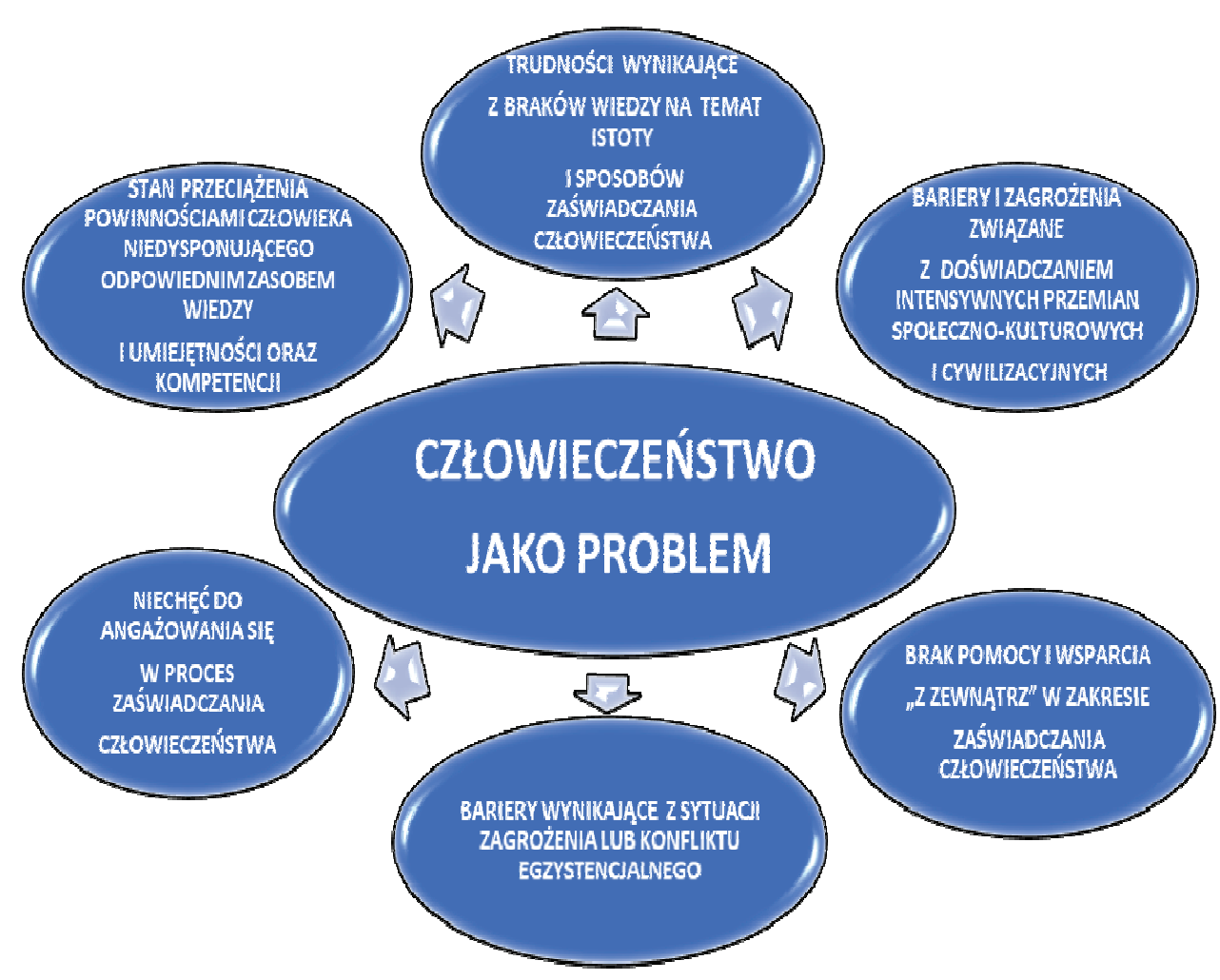

Rysunek 2. Człowieczeństwo z perspektywy problemu badawczego (wybór aspektów). Źródło: koncepcja własna.

Ujmowanie z takiej perspektywy kwestii człowieczeństwa jako przedmiotu badań pozwala dostrzegać jego inspirujący wymiar nie tylko ze względu na dotkliwie doświadczane luki w wiedzy na ten temat, lecz także nade wszystko dlatego, że dotyczy ludzkości i każdego człowieka z osobna, toteż tym bardziej wzbudza u ludzi ciekawość poznawczą w swej złożoności i niezgłębialności oraz motywuje do niekończących się zainteresowań poznawczych. Na bazie dotychczasowych osiągnięć, poglądów i stanowisk kwestia człowieczeństwa wzbudza aktywność poznawczą podążającą tropem możliwości odczytywania istniejącego dorobku, zgłębiania jego analizy i interpretacji wiodącej do dalszych poszukiwań i dociekań generujących rozliczne projekty badawcze, co summa summarum stanowi wielkiej wagi wyzwanie odnoszące się do wszystkich sfer życia człowieka i jego świata. 


\title{
3. WYZWANIE EDUKACYJNE
}

\author{
Educatio maximum diligentiam plurimumque \\ profuturum desiterat; facile est enim teneros \\ adhuc animos componere, difficulter reciduntur \\ vita quae nobiscum creverunt. \\ [Wychowanie wymaga jak największej dbałości \\ i przelicznych zabiegów ze względu na przyszłość. \\ Łatwo bowiem kształtować jeszcze młode dusze, \\ trudno natomiast ukrócić wady, które urosły wraz z nami.] \\ L. A. Seneka (1987, s. 86-87)
}

Termin „wyzwanie” należy do kategorii pojęciowej o niezbyt długiej tradycji i na ogół jest pomijany w kompendiach wiedzy albo wręcz zdawkowo w nielicznych bywa ujmowany. W swej istocie pojęcie to oznacza zazwyczaj wielorako złożone i trudne do realizacji przedsięwzięcie, któremu ze względu na znaczenie zarówno dla jednostek, jak i dla różnych zbiorowości społecznych przypisywana jest ranga szczególnie ważna. Współcześnie ów termin zdaje się być nadmiernie upowszechniany i nadużywany, a przy tym coraz częściej w sposób nieuprawniony bywa on odnoszony najczęściej do realizacji zadań raczej przeciętnych, które nie wymagają specjalnego zaangażowania oraz merytorycznego wtajemniczenia i określonych kompetencji. Tymczasem realizacja wyzwań zobowiązuje ludzi podejmujących je do wykazania się dużą koncentracją oraz kompetencjami, jak również gotowością do znacznego wysiłku i szczególnej determinacji, a także wytrwałości i poświęcenia, a niejednokrotnie nawet wykazania się heroizmem. Toteż dostrzeganie i artykułowanie wyzwań, a następnie wychodzenie im naprzeciw, po czym przystąpienie do ich realizacji oraz ewaluowania rezultatów w tej mierze (zarówno w toku realizacji, jak i po sfinalizowaniu wyzwania) stanowi niewątpliwie nie tylko sprawdzian czyjejś orientacji w określonych sytuacjach, lecz także służy jako weryfikator posiadanych przez kogoś zasobów wiedzy oraz doświadczeń, które z reguły stanowią solidną bazę warunkującą sposoby implementacji wyzwania. Ponadto wyzwania stanowią miernik siły woli, odporności i wytrwałości osób odpowiedzialnie i godnie je podejmujących oraz realizujących. Owe właściwości przypisuje się wszakże osobom zdolnym do dokonywania wielkich czynów i przezwyciężania nadzwyczajnych trudności i zagrożeń, a także gotowych do stawiania czoła nieoczekiwanym i często dramatycznym, a niekiedy nawet tragicznym okolicznościom. Niejednokrotnie realizacja wyzwań odnosi się do pokonywania przeszkód nie tylko 
zewnętrznych, lecz także wewnętrznych ludzi, takich na przykład, jak towarzyszące im wątpliwości dotyczące możliwości zrealizowania wyzwania, tudzież wiążącymi się z nim zasobami niepewności czy obawami oraz strachem bądź nawet cierpieniem. W realizacji wyzwań bez wątpienia niejednokrotnie nieodzowna jest siła woli i charakteru, a także hart ducha oraz wierność powinnościom i zasadom moralnym. W okolicznościach nadzwyczajnych w toku realizowania wyzwania nie jest wykluczana ewentualność dotycząca gotowości poświęcenia tego, co dla człowieka jest najcenniejsze w obronie szczególnie preferowanych i urzeczywistnianych przez niego wartości, np. szczęścia osobistego, zdrowia, a w sytuacjach ekstremalnych nawet życia. Wyzwania mogą być formułowane w odniesieniu do wszystkich sfer życia człowieka i są adresowane zarówno do osób, jak i do różnych zbiorowości oraz instytucji społecznych.

Główna uwaga w tej części rozważań koncentruje się wokół kwestii człowieczeństwa będącego wyzwaniem edukacyjnym. Z perspektywy podjętych w niniejszym tekście analiz ową kwestię sytuuję na kontinuum między zagrożeniem/trudnością/złożonością a potencjonalnością/szansą/realnością i nadzieją na osiąganie zamierzonych rezultatów w tej mierze. Owo wyzwanie edukacyjne dotyczy całokształtu etapów życia wszystkich ludzi jako homo educandus, którzy od początku swego rozumnego istnienia aż po kres życia uczestniczą - w różnym stopniu i zakresie - w rozmaitych konfiguracjach procesów edukacyjnych formalnych, nieformalnych i pozaformalnych z perspektywy integralnego rozwoju umysłowego, fizycznego, afektywnego, moralnego i duchowego. Istota tychże procesów summa summarum obejmuje swym zakresem nie tylko przekazywanie wiedzy i umiejętności, tudzież szeroko pojętych wartości kultury, lecz również inspiruje postawy twórcze, otwarte oraz motywuje do samodzielności myślenia i zdolności do samokształcenia w taki sposób, aby człowiek, zaświadczając jakość swojego człowieczeństwa, mógł integrować się w przestrzeni wszystkich sfer życia określonej wspólnoty, której jest cząstką. Na Rysunku 3 ujęto omówione w tej części artykułu konstytutywne aspekty człowieczeństwa jako wyzwania edukacyjnego.

Z perspektywy podjętych rozważań można wyłonić co najmniej trzy główne sekwencje człowieczeństwa jako wyzwania edukacyjnego, a mianowicie:

1) dostrzeganie i identyfikowanie tego fenomenu jako priorytetowego dla ludzkości z perspektywy edukacyjnej; 
2) wieloaspektowe poznawanie/urzeczywistnianie/spełnianie/wyrażanie/ zaświadczanie człowieczeństwa przez podmioty edukacji $\mathrm{w}$ toku procesów edukacyjnych;

3) doskonalenie aksjologicznej struktury człowieczeństwa w całożyciowym procesie budowania tego fenomenu przez człowieka.

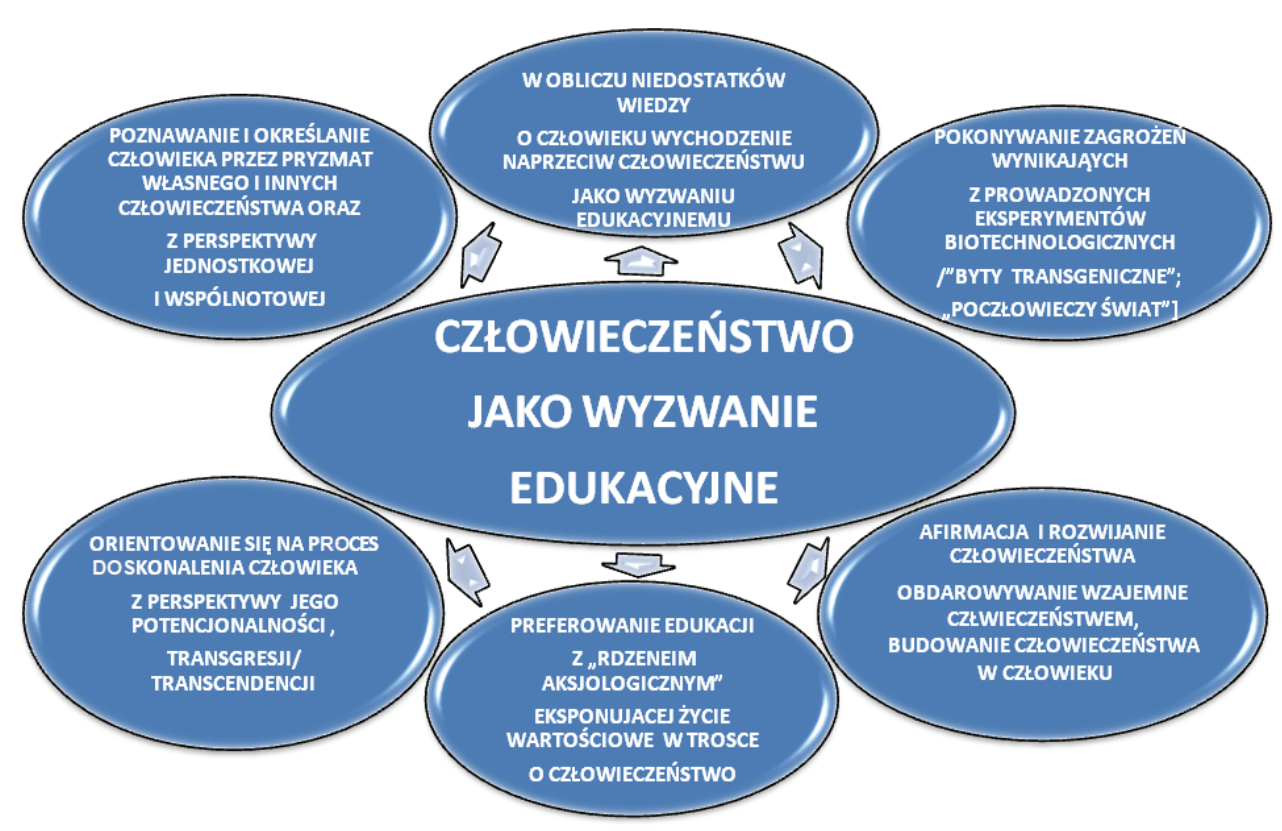

Rysunek 3. Człowieczeństwo jako wyzwanie edukacyjne (wybór konstytutywnych aspektów).

Źródło: koncepcja własna.

Realizacja owego wyzwania jest zatem ujmowana przez pryzmat całożyciowej drogi człowieka do „uczłowieczania”. Jednakże wychodzenie naprzeciw każdego wielkiej wagi wyzwania wymaga - według filozofa, logika i etyka, Tadeusza Czeżowskiego - krystalizowania charakteru człowieka za sprawą włożenia wysiłku w wykształcenie pożądanych cech i dyspozycji do trafnych ocen stanowiących zasady postępowania, jako że:

Kształcenie charakteru [...] polega przeto na wyrabianiu wspomnianych dyspozycji. Dochodzi się do tego drogą ćwiczenia w wydawaniu trafnych ocen, przez zastanawianie się nad własnym i cudzym postępowaniem, zwłaszcza takim, które nie doprowadziło do zadowalających rezultatów (Czeżowski, 1959, s. 278-279). 
Tego typu próby w różnym stopniu i zakresie podejmowano od czasów antycznych $\mathrm{z}$ tego względu, że właśnie $\mathrm{w}$ edukacji od jej zarania dostrzega się kluczowy czynnik zmian ukierunkowanych na przyszłość oraz przypisuje się jej podstawową rolę $\mathrm{w}$ rozwoju wszystkich sfer życia indywidualnego i społecznego. Już uczeń Sokratesa, Platon, w swoich dziełach wyrażał przekonanie, że rezultaty edukacji wpisują się trwale w całe życie człowieka oraz stwarzają mu możliwości spełniania się wartościowego, to znaczy wyboru dobra i piękna oraz unikania zła, otwierając przed nim w tenże sposób szanse na osiąganie wyższego poziomu człowieczeństwa (Platon, 1994, s. 63; Wasilewski, 2003, s. 292; Turos, 2003, s. 460). Edukacja bowiem „[...] to coś znacznie więcej niż tylko «wiedza ogólna» (ang. common knowledge). Zawiera ona w sobie nie tylko pewne umiejętności, lecz również podejście do rzeczywistości, podstawowe sposoby wartościowania, postawy estetyczne, moralne i polityczne" (Brezinka, 2005, s. 105). Trzeba jeszcze dodać do tego niezwykle istotny aspekt, zwracając uwagę na fakt, iż rezultaty procesów edukacyjnych wpisują się trwale w całokształt życia człowieka, których nikt nie jest w stanie nikogo ich pozbawić.

Czasy nowożytne zaświadczają różnorodne bogactwo sygnalizowania kwestii człowieczeństwa w edukacji, jednakże ze względu na ograniczoność miejsca nie sposób wyczerpująco odnieść się do całokształtu tejże problematyki. Odwołam się zatem do wybranych egzemplifikacji zaświadczających ów stan rzeczy.

Rozpocznę w tym miejscu od troski o człowieczeństwo pracowników nauki jako szczególnego rodzaju zobowiązania, na co zwracał uwagę Jan Paweł II, dla którego kwestia człowieczeństwa była kluczowa i sytuowana w różnych aspektach. W autobiografii Papież pisał następująco: „Być pracownikiem nauki, to zobowiązuje! Zobowiązuje przede wszystkim do szczególnej troski o rozwój własnego czlowieczeństwa" (Jan Paweł II, 2003, s. 71). W swej istocie człowieczeństwo jako wyzwanie edukacyjne stanowi podstawę dla wiedzy i praktyki wychowawczej. Odnosząc się do istoty człowieka i człowieczeństwa w zamieszczonym w Encyklopedii aksjologii pedagogicznej haśle, jego autor odwołał się do Karola Wojtyły, który określił wychowanie „obdarzaniem człowieczeństwem - obdarzeniem dwustronnym” (Kozłowski, 2016, s. 2017-2018). Warunkiem sine qua non owego obdarzania/obdarowywania jest wszakże posiadanie tego, czym zamierza się kogoś obdarować. W ubiegłym stuleciu twórczyni pedagogiki specjalnej, Maria Grzegorzewska (1888-1967), w pisanych do młodego nauczyciela listach następująco zwracała uwagę na kwestię człowieczeństwa, będącego najbardziej istotną i podstawową 
wartością w jego pracy: „[...] poza przygotowaniem zawodowym człowieka, poza jego wykształceniem najistotniejszą, najbardziej podstawową i decydującą wartością jego pracy jest jego czlowieczeństwo" (Grzegorzewska, 1998, s. 18). Z kolei ks. Janusz Tarnowski (1919-2012), prekursor pedagogiki chrześcijańskiej w Polsce i twórca pedagogiki personalno-egzystencjalnej, eksponował $\mathrm{w}$ procesie edukacji rolę pomocy w urzeczywistnianiu i rozwijaniu tego fenomenu, toteż wychowanie postrzegał jako ,,[... [ całokształt sposobów i procesów pomagających istocie ludzkiej, zwłaszcza przez interakcję, urzeczywistniać i rozwijać swoje czlowieczeństwo" (Tarnowski, 1992, s. 86). Natomiast ks. Marian Nowak (ur. 1955), prezentując koncepcję pedagogiki otwartej w ujęciu dynamicznym w inspiracji chrześcijańskiej, zwraca uwagę na dynamikę procesu wzrastania w człowieczeństwie i stwierdza, że prawdziwie wychowawczym działaniem jest jedynie takie, które wspiera „[...] we wzrastaniu w «człowieczeństwie» (w «humanistas») i w działaniu na rzecz pobudzania do osobowego sposobu życia, a więc wzbudzenia osoby [...]" (Nowak, 1999, s. 271). Zaledwie kilka przywołanych egzemplifikacji konstruuje istotne przesłanki wpisujące się w drogę wychodzenia naprzeciw człowieczeństwu jako wyzwaniu edukacyjnemu, od szczególnej troski o rozwój własnego człowieczeństwa pracowników nauki i nauczycieli poczynając, i w ślad za tym, za sprawą dwustronnego obdarzania się człowieczeństwem w edukacji, stanowiącym warunek sine qua non uobecniania się tego fenomenu w pracy nauczyciela wychowawcy, poprzez pomoc i wsparcie w urzeczywistnianiu i rozwijaniu człowieczeństwa w procesie edukacji aż do wzrastania w człowieczeństwie w całokształcie życia człowieka.

$\mathrm{W}$ toku wychodzenia naprzeciw człowieczeństwu jako wyzwaniu edukacyjnemu można podejmować tego typu próby, jakie w latach osiemdziesiątych ubiegłego stulecia zaproponował pedagog, teoretyk wychowania, fenomenolog personalista, Stanisław Ruciński (1931-2014), a mianowicie w postaci kreowania szlachetnie zakreślonej drogi „wprowadzania w życie wartościowe" młodych pokoleń przez mądrych nauczycieli wychowawców w horyzoncie Korczakowskiego sposobu „szukania własnej drogi”, w orientacji nie do odrzucenia następującej propozycji:

[...] chcesz wejść w życie wartościowe? To chodź i spróbuj iść obok, niech będzie to twoim zabezpieczeniem, bo chcę, abyś czuł, że nie jesteś sam, że nie będziesz zdatny tylko na siebie, kiedy nie będziesz wiedział, co się z tobą dzieje, kiedy zamąci ci się widzenie twojej sytuacji i czucie wartości, które cię ku sobie wzywają. Możesz zwrócić się do mnie, abym pomógł ci wyraźniej zobaczyć, głębiej zrozumieć (Ruciński, 1982, s. 163). 
Oczywiście na drodze do urzeczywistniania człowieczeństwa ze wszech miar warto i trzeba odwoływać się do wrażliwości pisarzy i poetów oraz pochylać nad mądrością przesłania ich twórczości zawierającej wiele ważnych tropów w tej mierze. Wiele inspiracji wychodzących naprzeciw człowieczeństwu jako wyzwaniu edukacyjnemu zawierają prace naukowe, których autorzy podejmujący tę problematykę odnoszą się do ważnych aspektów dotyczących zaświadczania człowieczeństwa.

Każda droga ma swój kontekst, który jest niezwykle ważny i pouczający dla osób ją pokonujących oraz czerpiących z niej nauki. Niezwykle cenne podstawy oraz ukierunkowanie dla owego edukacyjnego wyzwania zawierają prace, które są nie tylko rezultatem prowadzonych przez ich autorów badań teoretycznych i empirycznych, lecz także z tego względu, że wyrosły one na fundamentach prowadzonych dialogów z nauczycielami i dyrektorami szkó oraz z rodzicami uczniów na temat edukacji aksjologicznej i wychowania ku wartościom dzieci i młodzieży, w tym osiągania pełni człowieczeństwa. W rozległym zakresie kontekst tego typu prezentują rozważania zawarte w pracy Krystyny Chałas i Małgorzaty Łobacz, poświęconej zagadnieniom edukacji aksjologicznej i wychowaniu ku wartościom (Chałas, Łobacz, 2020, s. 39, passim).

Cenne propozycje $\mathrm{w}$ tej mierze zawiera publikacja prezentująca projekty edukacyjne w świetle nauczania Jan Pawła II, której autorami są Krystyna Chałas i ks. Adam Maj. Jeden z projektów (spośród stu, które zamieszczono w pracy) zatytułowano: „Człowieczeństwo darem dla wszystkich - darem dla nas młodych" (Chałas, Maj, 2020, s. 395-398).

W konwencję człowieczeństwa jako wyzwania edukacyjnego wpisują się również rozważania W. Stróżewskiego, który wypowiadając się na temat realizacji tego fenomenu, przypisywał istotną rolę tzw. prawdziwemu człowiekowi następująco:

Wszędzie tam, gdzie mówimy: „prawdziwy człowiek”, myślimy o człowieku, który zrealizowal swe człowieczeństwo. Człowieczeństwo, to po łacinie humanitatis. W tej idei znajdują szczególne miejsce spotkania filozofia i paideia; pierwsza, by ją odsłaniać, druga - pomagać wedle niej właśnie kształtować człowieka (Stróżewski, 1993, s. 5).

W istocie nie trzeba specjalnie uzasadniać, że spotkania filozofii i pedagogiki kreują dla współczesnej edukacji znamienny horyzont problemowy, w którym szczególne miejsce zajmują konstytutywne pytania, zwłaszcza co najmniej dwa postawione przez filozofa, na które - jak sam zastrzegł - nie 
odważy się udzielić odpowiedzi: „,...] 1. Jak określić, zdefiniować człowieczeństwo? 2. Jak realizować - czyli: jak budować człowieka w człowieku? Pierwsze jest zadaniem filozofii. Drugie - pedagogiki" (Stróżewski, 1993, s. 5). Cytowany powyżej fragment został zaczerpnięty z tekstu, któremu w tytule autor przypisał następujący status: „kilka myśli niedokończonych”. W ten sposób filozof zapewne skłania szczególnie zainteresowanych ową problematyką odbiorców jego dzieła do podejmowania pogłębionych w tej mierze refleksji oraz do kontynuowania eksploracji inspirująco zasygnalizowanych kwestii w odniesieniu do ewentualnego „dokończenia” owych „niedokończonych myśli”, choćby w postaci publikowania prac na ten temat, ale przede wszystkim za sprawą zaświadczania człowieczeństwa własnym postępowaniem. W procesach edukacji ze wszech miar zasadną odpowiedzią na owe pytania jest bez wątpienia wdrażanie uczniów/wychowanków do takiego właśnie postępowania, i to niekoniecznie za sprawą rozgraniczenia pytań, które są przynależne filozofii, i tych, które należą do pedagogiki, gdyż bardziej zasadne $\mathrm{w}$ tej mierze jest podejście synergiczne. Warto przypomnieć, że wielu filozofów w czasach antycznych tak właśnie czyniło, zajmując się czynnie sprawami edukacji, np. zakładając szkoły czy wychowując w nich swoich uczniów oraz wygłaszając poglądy pedagogiczne także w swoich dziełach zawierających ważne przemyślenia i rady nacechowane treściami wychowawczymi, m.in. zaświadczają o tym fragmenty dzieł stanowiących motto do części drugiej niniejszego tekstu, zaczerpnięte z pracy Epikteta, i do części trzeciej, pochodzące z dzieła Seneki. Otóż pedagogika, jak wiadomo, wyrosła z filozofii i przez cały czas swego istnienia, rozwijając się intensywnie, ewidentnie zaświadcza związki z tą dyscypliną. Wzajemne związki między filozofią i pedagogiką są wielopłaszczyznowe i wieloaspektowe, w tym co najmniej dwukierunkowe. Pedagogice niezbędna jest filozofia, zwłaszcza w kwestii określania celów, a także ich ewaluacji i weryfikacji oraz treści zasad i metod wychowania. Nie bez racji określa się niekiedy tę dziedzinę wiedzy i praktyki pedagogicznej jako filozofię wychowania czy szerzej - filozofię edukacji. Proces edukacji, wpisujący się znacząco w strukturę kreowania ludzkiego sposobu bycia, stanowi przedmiot refleksji filozofii aspirującej do integralnego sposobu mówienia o człowieku, w tym o jakości jego conditio humana, o pretendowaniu do osiągania pełni człowieczeństwa. Istota owych związków jest coraz wyraźniej dostrzegana w literaturze przedmiotu, jako że zarówno filozofia, jak i pedagogika ustawicznie stawiają sytuowane $\mathrm{w}$ różnych kontekstach problemowych pytanie o człowieczeństwo. 
Tak oto piszą na ten temat autorzy jednej z prac, odwołując się do głównego zadania pedagogiki, którym jest

[...] wychowanie człowieka, rozwinięcie wartości powszechnych istotnych dla osoby ludzkiej. Także pedagogika zakłada więc pytanie o człowieczeństwo człowieka: „kim jest człowiek”? I „kim być może”? Tak więc pedagogika, podobnie jak filozofia, urzeczywistnia się w żywiole prawdy i mądrości. Filozofia i pedagogika nie pozostają więc ze sobą jedynie w zewnętrznej relacji, ale wyrastają z tego samego źródła: c z ł o w i e k [podkr. źródłowe] i dążą do tego samego celu: mądrość w aspekcie teoretycznym i praktycznym. Jeśli filozofia jest „miłością mądrości”, pedagogika jest „mądrością miłości” (Kaczmarek, Gadacz, 1993, s. 60).

Szeroki horyzont problemowy dla owych wielorakich i nierozerwalnych związków, i to nie tylko w odniesieniu do pedagogiki, zakreślił nestor polskich pedagogów, historyk dziejów wychowania, oświaty i myśli pedagogicznej oraz pedeutolog, Stefan Wołoszyn (1911-2004), pisząc na ten temat następująco:

\begin{abstract}
Nie ma wiedzy i poglądów naukowych bez prześwietlającego je pierwiastka filozoficznego; co więcej, żywość i doniosłość problematyki filozoficznej w obrębie konkretnej dyscypliny naukowej [...] świadczy o żywotności i wadze danej nauki. Jest świadectwem tego, że dana nauka widzi, stawia i stara się rozwiązywać zagadnienia istotne $\mathrm{i}$ ważne tak dla poznania, jak i dla bytu oraz praktyki życiowej człowieka (Wołoszyn, 1998, s. 171-172).
\end{abstract}

Aktualność i ważność pytania o istotę człowieczeństwa nasila się wraz $\mathrm{z}$ dokonywanymi obecnie eksperymentami biotechnologicznymi, w wyniku których (za pomocą genetycznych manipulacji instrumentalnych i antropologicznych) powstają różnego rodzaju „,byty transgeniczne” - „ludzkie-nieludzkie". Owe trendy stanowią poważne zagrożenie nie tylko dla wyróżniającego się spośród wszystkich innych istot żywych człowieka, lecz także zagrażają istocie człowieczeństwa $\mathrm{z}$ racji podążania ku „poczłowieczemu światu". Taki stan rzeczy wywołuje wiele obaw ludzi zatroskanych o istotę człowieczeństwa ${ }^{10}$, w tym m.in. amerykańskiego politologa, filozofa politycznego i ekonomisty japońskiego pochodzenia, Francisa Fukuyamy (ur. 1955) (Fukuyama, 2004). Ewidentnie naprzeciw owym zagrożeniom wychodzi filozof, specjalizujący się w zagadnieniach etycznych, zajmujący się zwłaszcza problematyką bioetyki, ekologii, inżynierii genetycznej oraz diagnostyki prenatalnej, Tadeusz Ślipko (1918-2015), stwierdzający, że życie czy egzystencja człowieka, z perspektywy eksplikowania chrześcijańskiego stanowis-

\footnotetext{
${ }^{10}$ Pisałam o tym szerzej w innym miejscu (zob. Ostrowska, 2021b).
} 
ka, nie są pojmowane jako jakaś część jego realnego bytu, swoistego dobra, które można wyodrębnić z całokształtu człowieczeństwa, i uzasadnia, że życie należy pojmować integralnie jako istnienie tożsame z całą realną podmiotowością człowieka. Życie człowieka nie jest bowiem czymś w człowieku, ale jest samym żyjącym człowiekiem, któremu przysługuje nie tylko doskonałość ontyczna, lecz także fundamentalna godność i wartość moralna. W ten sposób życie ludzkie zostaje włączone w etyczną treść osoby i razem z nią nabiera sensu wartości nadrzędnej - jest niepogwałcalne (Ślipko, 2019, s. 309-310). Zasygnalizowany wątek etyczny uobecnia się również w rozważaniach Elzenberga, który wskazuje na podstawy - jak sam to określa - programu etycznego w ramach „doskonalenia się” człowieka i jego człowieczeństwa. Można je uznać, jak sądzę, za swoiste podsumowanie przeprowadzonych w artykule rozważań. Otóż autor uzasadnia, że wszelkie przedsięwzięcia etyczne człowiek winien rozpoczynać od siebie samego, albowiem „Dobro w świecie odkrywamy w miarę, jak sami stajemy się lepsi; doskonalenie się etyczne jest nieodzownym warunkiem przebicia się do świata wartościowego; [...] organem poznania świata wartościowego jest wartość osobista poznającego" (Elzenberg, 1994, s. 278). Niemniej w odniesieniu do uwarunkowań realizacji owego programu zastrzega następująco:

[...] jakże mi myśleć o ulepszeniu czegoś poza mną, jeśli ja sam jestem nic niewart? Trzeba się doskonalić samemu, by stać się powołanym narzędziem doskonalenia drugich, czyli świata. Doskonalenie świata przez kogoś, kto nie dba o wartość swą własną, sprawia wrażenie absurdu (Elzenberg, 1994, s. 271).

\section{UWAGI NA ZAKOŃCZENIE}

Z przeprowadzonych rozważań wynika, że dla edukacji człowieczeństwo jest problemem i wyzwaniem prymarnym na wszystkich jej etapach i poziomach. Wychodzenie naprzeciw owemu problemowi i wyzwaniu o aksjologicznej strukturze universum antroposferycznego wytycza drogę, która conditio sine qua non wiedzie przez świat wartości w kierunku czynienia człowieka i jego świata lepszym, bardziej etycznym, przyjaznym ludziom i zarazem stwarzającym szanse na doskonalenie się w nim, skłaniającym do zaświadczania człowieczeństwa i ustrzeżenia przed zgubieniem tego fenomenu w labiryncie skomplikowanych dróg w świecie o narastającej złożoności. Szczególną rolę w tej mierze należy przypisać edukacji z „rdzeniem aksjologicznym”, wychodzącej naprzeciw powinności wprowadzania w życie wartościowe, 
w którym człowiek w sposób najpełniejszy ma szansę poznawać istotę, rozwijać, doskonalić oraz urzeczywistniać i zaświadczać swoje człowieczeństwo. Sytuowanie podjętej problematyki na kontinuum między zagrożeniem/ trudnością/złożonością a potencjonalnością/szansą/realnością i nadzieją uzasadnia uwzględnianie pełnego w swej różnorodności i wielości bogactwa, możliwego do zaświadczania, rozwijania i doskonalenia człowieczeństwa na nieskończenie wiele sposobów we wszystkich powiązanych ze sobą wielorako wymiarach rzeczywistości człowieka i jego świata. W przypadkach ewentualności zagrożeń dla człowieczeństwa edukacja pełni niezwykle istotną rolę w zakresie podejmowania przedsięwzięć ocalenia podstaw zagrożonego człowieczeństwa, jako zagrożonego dobra oraz wartości trwałych. W interdyscyplinarnym piśmiennictwie przedmiotu kwestia człowieczeństwa jako problem i wyzwanie edukacyjne znajduje swoje odzwierciedlenie w postaci wielości ujęć problemowych zaświadczających o bogactwie w swej złożoności i różnorodności, którą konstruują takie zwłaszcza konstytutywne elementy, jak: idea człowieczeństwa jako miara, wzór, drogowskaz (J. Szczepański); człowieczeństwo godnością, którą trzeba zdobyć (Vercors); człowieczeństwo uniwersalną wartością najwyższą w antroposferze (M. Gołaszewska); aksjologiczna struktura człowieczeństwa (U. Ostrowska); wyznaczniki człowieczeństwa (H. Elzenberg); aksjonormatywne pojmowanie człowieczeństwa (T. Czeżowski); wyrastanie ponad naturę człowieczeństwem (R. Ingarden); urzeczywistnianie własnego człowieczeństwa (W. Cichoń); troska o rozwój własnego człowieczeństwa (Jan Paweł II); obdarzanie człowieczeństwem obdarzenie dwustronne (Karol Wojtyła); człowieczeństwo wartością pracy nauczyciela (M. Grzegorzewska); pomaganie w urzeczywistnianiu i rozwijaniu człowieczeństwa (J. Tarnowski); wspieranie we wzrastaniu w człowieczeństwie (M. Nowak); osiąganie pełni człowieczeństwa (K. Chałas i M. Łobacz); człowieczeństwo darem (K. Chałas i A. Maj); pełnia człowieczeństwa (J. Mariański); kiedy mówimy „prawdziwy człowiek”, myślimy o człowieku, który zrealizował swe człowieczeństwo (W. Stróżewski); całokształt człowieczeństwa (T. Ślipko); zaświadczanie człowieczeństwa (U. Ostrowska); afirmacja człowieczeństwa (R. Kozłowski).

$\mathrm{Z}$ jednej strony architektonika owych konstytutywnych elementów uwyraźnia rezultat dociekań na ten temat, $\mathrm{z}$ drugiej strony otwiera szeroki horyzont problemowy skłaniający do podążania wytyczonym tropem w kierunku zgłębiania nie mającej kresu kwestii człowieczeństwa. 


\section{BIBLIOGRAFIA}

BREZINKA, W. (2005). Wychowanie i pedagogika w dobie przemian kulturowych. Tłum. J. Kochanowicz. Kraków: WAM.

Camus, A. (1987). Dżuma. Upadek. Tłum. J. Guze. Warszawa: PIW.

ChaŁas, K., Łobacz, M. (2020). Przymioty osoby ludzkiej, edukacja aksjologiczna i wychowanie $k u$ wartościom. Elementy teorii i praktyki. Lublin: Wydawnictwo KUL.

ChaŁAs, K., MAJ, A. ks. (2020). Nauczanie Jana Pawła II w procesie wychowawczo-dydaktycznym szkoły. T. 1: Edukacyjne projekty droga zgłębienia nauczania Jan Pawła II. Kraków: Wydawnictwo „Scriptum”.

CichoŃ, W. (1996). Wartości - Człowiek - Wychowanie. Zarys problematyki aksjologiczno-wychowawczej. Kraków: Wydawnictwo Uniwersytetu Jagiellońskiego.

CZAPIŃSKi, L. (1892). Księga przysłów, sentencji i wyrazów łacińskich używanych przez pisarzy polskich. Warszawa: Druk S. Olgebranda Synów.

CzEżowsKi, T. (1959). O postępowaniu. W: T. CzEżowsKI, Główne zasady nauk filozoficznych (s. 179-219). Wrocław: Zakład Narodowy im. Ossolińskich.

Czeżowski, T. (1989). Trzy postawy wobec świata. W: P. J. SMOCZyŃski (red.), Tadeusz Czeżowski. Pisma z etyki i teorii wartości (s. 45-46). Wrocław: Zakład Narodowy im. Ossolińskich.

Elzenberg, H. (1966). Ideał zbawienia na gruncie etyki czystej. W: H. ElzenBerg, Wartość i człowiek. Rozprawy z humanistyki i filozofii (s. 94-112). Torun: Wydawnictwo Naukowe UMK.

Elzenberg, H. (1994). Klopot z istnieniem. Aforyzmy w porządku czasu. Wyd. 2. Kraków: Wydawnictwo Znak.

EPIKTEt. (1961). Diatryby Encheiridion z dodatkiem Fragmentów oraz Gnomologium Epiktetowego. Z języka greckiego przełożył i opracował L. Jachimowicz. Warszawa: PWN.

Fukuyama, F. (2004). Koniec człowieka. Konsekwencje rewolucji biotechnologicznej. Tłum. B. Pietrzyk. Kraków: Wydawnictwo Znak.

GajdA, J. (2003). Człowieczeństwo. W: T. PILCH (red.), Encyklopedia pedagogiczna XXI wieku (t. 1, s. 575-580). Warszawa: Wydawnictwo Akademickie „Żak”.

GolASZEwSKA, M. (1990). Istota i istnienie wartości. Studium o wartościach estetycznych na tle sytuacji aksjologicznej. Warszawa: PWN.

Grzegorzewska, M. (1998). Listy do mtodego nauczyciela. Cykl I-II. Warszawa: Akademia Pedagogiki Specjalnej.

INGARDEN, R. (1973). O naturze ludzkiej. W: R. Ingarden, Książeczka o człowieku (s. 17-23). Kraków: Wydawnictwo Literackie.

JAeger, W. (1964). Paideia. T. 1-2. Tłum. M. Plezia. Warszawa: Instytut Wydawniczy PAX.

JAN PAWEŁ II (1988). „W imię przyszłości kultury”. Przemówienie wygłoszone w siedzibie UNESCO, Paryż, 2.06.1980. W: M. RADWAN i in. (red.), Jan Pawet II. Wiara i kultura. Dokumenty, przemówienia, homilie (s. 55). Rzym-Lublin: Redakcja Wydawnictw KUL.

Jan Pawet II. Autobiografia (2003). Wybrała i ułożyła J. Kiliańczyk-Zięba. Kraków: Wydawnictwo Literackie.

KozŁowski, R. (2016). Człowieczeństwo. W: K. ChaŁAs, A. MAJ (red.), Encyklopedia aksjologii pedagogicznej (s. 2017-2018). Radom: Polskie Wydawnictwo Encyklopedyczne Polwen. 
KumANIECKi, K. (1965). Stownik łacińsko-polski. Warszawa: PWN.

LuCJusz AnNeusz SeneKa (1987). Myśli. Wybrał, przełożył i opracował S. Stabryła. Kraków: Wydawnictwo Literackie.

MARIAŃSKI, J. (2017). Godność ludzka jako nowy paradygmat w socjologii moralności. Uniwersyteckie Czasopismo Socjologiczne, 21(4), 9-20.

Markiewicz, M., Romanowski, A. (1990). Skrzydlate słowa. Warszawa: PIW.

Nowak, M. (1999). Podstawy pedagogiki otwartej. Ujęcie dynamiczne w inspiracji chrześcijańskiej. Lublin: Redakcja Wydawnictw KUL.

OstrowsKa, U. (2020). Doświadczanie conditio humana przez człowieka wspótczesnego. W trosce o człowieczeństwo z perspektywy aksjologicznej. Gorzów Wielkopolski: Wydawnictwo Akademii im. Jakuba z Paradyża w Gorzowie Wielkopolskim.

Ostrowska, U. (2021a). „A jeżeli powiem, że [...] bezmyślnym życiem żyć człowiekowi nie warto [...] tylko przekonać kogoś o tym nie jest łatwo". Wokót potencjatu sokratejskiego dialogu i paidei, w druku.

OstrowsKa, U. (2021b). Antropologia i pedagogika w kręgu wiedzy nauk o człowieku, w druku.

Platon. (1994). Państwo. T. 2. Tłum. W. Witwicki. Warszawa: Wydawnictwo ALFA.

RUCIŃSKI, S. (1982). Wychowanie jako wprowadzenie w życie wartościowe: próba marksistowskiego określenia aksjologicznej i metodologicznej problematyki ideału wychowawczego. Warszawa: Wydawnictwo Uniwersytetu Warszawskiego.

Stroh, W. (2013). „Łacina umarła, niech żyje łacina!” Mała historia wielkiego języka. Tłum. A. Arnd, wstęp E. Wesołowska. Poznań: Wydawnictwo Poznańskiego Towarzystwa Przyjaciół Nauk.

STRÓŻEWSKI, W. (1992). W kręgu wartości. Kraków: Wydawnictwo Znak.

STRÓŻEWSKI, W. (1993). O stawaniu się człowiekiem (kilka myśli niedokończonych). W: F. ADAMSKI (red.), Człowiek - wychowanie - kultura (s. 52-58). Kraków: Wydawnictwo Akademii Muzycznej.

STRÓŻEWSKI, W. (2002). O wielkości. Szkice z filozofii człowieka. Kraków: Wydawnictwo Znak.

SzCZEPAŃSKI, J. (1980). Sprawy ludzkie. Warszawa: Spółdzielnia Wydawnicza Czytelnik.

Szostek, A. (1998). Wokół godności, prawdy i miłości. Lublin: Wydawnictwo KUL.

SzTUMSKI, J. (1994). Człowieczeństwo jako efekt rozwoju i alienacji gatunku ludzkiego. W: S. Folaron (red.), Człowieczeństwo - iluzja czy rzeczywistość (s. 155). Częstochowa: Wydawnictwo WSP.

ŚLIPKO, T. (2019). Bioetyka. Najważniejsze problemy. Kraków: Wydawnictwo Naukowe Akademii Ignatianum.

TARnOwSKI, J. (1992). Pedagogika dialogu. W: B. ŚLIWERSKI (red.), Edukacja alternatywna - dylematy teorii i praktyki (s. 112-122). Kraków: Oficyna Wydawnicza „Impuls”.

Turos, L. (2003). Platon o człowieku, kulturze i wychowaniu. Pedagogiczne i andragogiczne aspekty platońskiego dziedzictwa myślowego. Warszawa: Wydawnictwo Ypsylon.

VerCORS [Jean Marcel Bruller] (1956). Zwierzęta niezwierzęta. Tłum. J. Dackiewicz. Warszawa: PIW.

WASILEWSKI, M. (2003). O platońskiej definicji wychowania z pierwszej księgi „Praw”. W: S. SzTOBRYn, B. ŚliWERSKI (red.), Idee pedagogiki filozoficznej (s. 288-296). Łódź: Wydawnictwo Uniwersytetu Łódzkiego. 
Wasilewski, M. (2007). Paideutyka Protagorasa i Platona. Poznań: Wydawnictwo Naukowe Polskiego Towarzystwa Pedagogicznego.

WinNiczuK, L. (1985). Ludzie, zwyczaje i obyczaje starożytnej Grecji i Rzymu. Cz. 1. Warszawa: Wydawnictwo Naukowe PWN.

WoŁoszyn, S. (1998). Nauki o wychowaniu w Polsce XX wieku. Próba syntetycznego zarysu na tle powszechnym. Kielce: Dom Wydawniczy Strzelec.

\section{CZŁOWIECZEŃSTWO JAKO PROBLEM I WYZWANIE EDUKACYJNE}

\section{STRESZCZENIE}

Kwestia sposobów zaświadczania człowieczeństwa przez ludzi współczesnych przybiera rangę priorytetowego zadania współczesności i wyzwania wykraczającego w przyszłość. Zawarta w tytule artykułu triada kategorii kluczowych: człowieczeństwo - problem - wyzwanie edukacyjne stanowi tropy wytyczające tok rozważań podjętych w niniejszym tekście. Rozpoczynam je od ujęć terminologicznych, a następnie prezentuję podjęte kwestie $\mathrm{z}$ jednej strony $\mathrm{z}$ perspektywy postrzegania człowieczeństwa jako priorytetowego problemu i wyzwania dla ludzkości, który wymaga intensywnych zabiegów epistemologiczno-eksploracyjnych, z drugiej strony jako konstytutywnej podstawy dla teorii i praktyki edukacyjnej ukierunkowanej na wnikliwe poznawanie człowieczeństwa, a także odpowiedzialne zaświadczanie przez podmioty edukacyjne tego fenomenu w universum antroposferycznym, w którym podejmowane próby doskonalenia elementów świata wartości nie mają kresu.

Słowa kluczowe: człowieczeństwo; problem; wyzwanie edukacyjne universum antroposferycznym.

\section{HUMANITY AS AN PROBLEM AND EDUCATIONAL CHALLENGE}

\section{SUMMARY}

The issue of the ways of certifying humanity by contemporary people takes the rank of a priority task today and a challenge that goes into the future. The triad of key categories contained in the title of the article: humanity - problem-educational challenge constitute the clues that define the course of considerations undertaken in this text. I start them with terminological approaches, and then present the issues raised on the one hand from the perspective of perceiving humanity as a priority problem and challenge for humanity, which requires intensive epistemological and exploratory efforts, and on the other hand as a constitutive basis for educational theory and practice focused on insightful learning of humanity, as well as responsible certification by educational entities of this phenomenon in the anthropospheric universe in which attempts to improve elements of the world of values have no end.

Keywords: humanity; problem; educational challenge; antropospheric universe. 